\title{
GEOPHYSICAL CHARACTERISTICS OF THE TOW VALLEY FAULT ZONE IN NORTH-EAST IRELAND
}

\author{
PAUL J. GIBSON
}

(Received 9 January 2003)

\begin{abstract}
The Tow Valley Fault Zone in north-east Ireland consists of number of ENE-WSW trending major fault segments and shorter $\mathrm{N}-\mathrm{S}$ ones with different dips, downthrows and geophysical characteristics. The fault zone is associated with high magnetic gradients and a marked north-westerly decrease in gravity. Modelling of gravity data suggests that near Garvagh (south-west) and Ballycastle (north-east) the major fault plane dips to the north-west at about $20^{\circ}-25^{\circ}$ whereas the central section dips at $56^{\circ}$ to the north-west. Thick sediments $(c .2 .4 \mathrm{~km})$, mainly PermoTriassic in age, occur beneath the Tertiary basalts north-west of the fault zone. Ground-based magnetic profiles across the fault zone yield a range of signatures. At some localities the fault is characterised by a $1 \mathrm{~km}$-wide zone of fracturing in the Tertiary basalts. Seismic data indicate that the fault zone continues offshore to the north-east of Rathlin Island.
\end{abstract}

\section{Introduction}

The 1:250,000 geological map of northern Ireland shows the Tow Valley Fault as a $50 \mathrm{~km}$ long ENE-WSW trending lineament (Fig. 1, Geological Survey of Northern Ireland 1997). The fault forms part of a much larger structure, the Fair Head-Clew Bay Lineament (FCL, Fig. 1 ), which extends for $285 \mathrm{~km}$ across Ireland and has been correlated with major structures in northern Britain to the east and North America in the west (e.g. Dewey and Shackleton 1984; Hutton 1987). This lineament is characterised by a steep magnetic gradient for most of its length and a steep gravity gradient in north-east Ireland (British Geological Survey 1997; 1998). The lithologies of the Fair Head-Clew Bay Lineament in north-east Ireland are totally different from the Clew Bay region in western Ireland. Most geological work has been concentrated in the Clew Bay section of the lineament where the Deer Park Complex, which has been interpreted as a terrane boundary (Murphy et al. 1991), consists of a north-dipping ophiolitic melange composed of serpentinite, carbonate-talc schists and metagabbro (Ryan et al. 1983).

For most of its length in north-east Ireland, the Tow Valley Fault Zone juxtaposes the Tertiary (Palaeocene) Upper Basalt Formation to the north-west with the Lower Basalt Formation to the south-east (Fig. 1). The fault has a demonstrable downthrow of $230 \mathrm{~m}$ in Tertiary rocks near Ballycastle. The Oligocene Lough Neagh Group was deposited in shallow lacustrine basins near Ballymoney, which are 


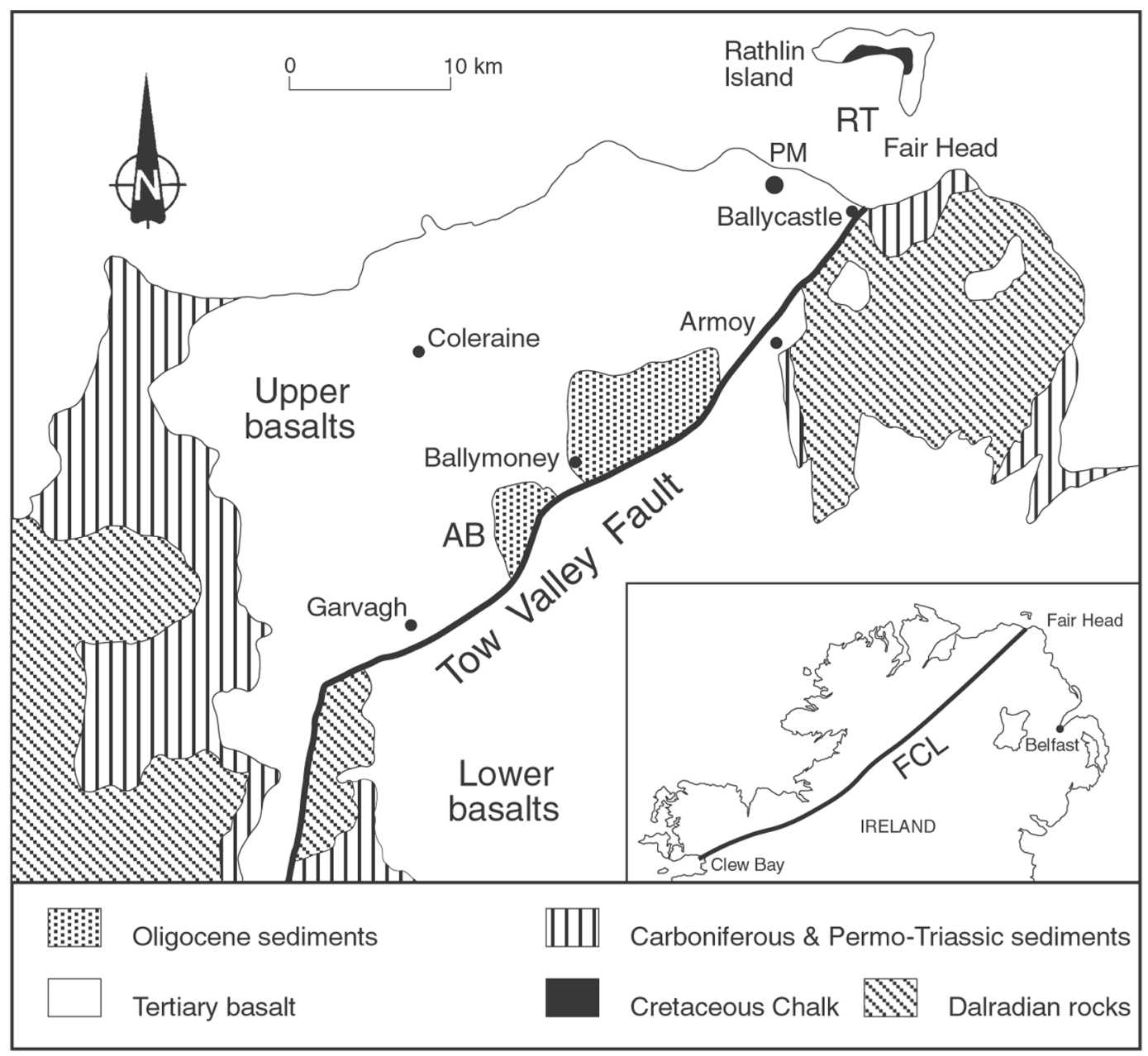

Fig. 1-Geological map of north-east Ireland, modified after Geological Survey of Northern Ireland (1997). FCL: Fair Head—Clew Bay Lineament; PM: Port More Borehole; RT: Rathlin Trough; AB: Agivey Basin.

bounded on their south-eastern edge by the Tow Valley Fault Zone (Geological Survey of Northern Ireland 1999). This group predominantly consists of clays with infrequent sandy seams and multiple lignite layers (Parnell et al. 1989). The fault forms the north-western edge of the Highland Border Ridge in north-east Ireland, where Upper Dalradian quartzose schists and schistose grits are exposed. No Dalradian rocks are exposed north-west of the fault in north-east Ireland. The conglomeratic lower part of the lower Old Red Sandstone south of the Highland Border Ridge does not have a local provenance but was derived from a source area farther to the north (Simon 1984). However, sediments in the upper part of the lower Old Red Sandstone have a local source and are believed to mark the initial stage in the uplift of the ridge and vertical movement on the Tow Valley Fault Zone (Sanderson 1970). Vertical movement with a north-west downthrow on the fault continued in the Mesozoic. Drilling by Meekatharra in the 1980s adjacent to and south-east of the Tow Valley Fault Zone indicates that Mesozoic sediments are relatively thin, whereas data from the Port More borehole, north-west of the fault zone, show that the base of the Permo-Trias had still not been reached at a depth of approximately 1900m (Wilson and Manning 1978). Thus a basin of considerable depth (known as the Rathlin Trough) exists north-west of the fault beneath the basalt. Exposures are very limited near the Tow Valley Fault Zone, and the Quaternary North Antrim End Moraine is 
aligned along part of it with up to $40 \mathrm{~m}$ of glacial sediments in places. Consequently, it is necessary to use geophysical methods in order to investigate the Tow Valley Fault Zone. The following techniques are employed:

(1) gravity and aeromagnetic data are digitally processed in order to produce geophysical images of the fault;

(2) three gravity profiles are modelled in order to investigate changes across the Tow Valley Fault Zone;

(3) ground-based magnetic profiles across the fault are examined;

(4) the offshore continuation of the Tow Valley Fault Zone is analysed using seismic data.

\section{Gravity and aeromagnetic images of study area}

Gravity and aeromagnetic data allow the gross geophysical characteristics of the Tow Valley Fault Zone to be displayed, usually as contour plots. However, it is possible to produce 'images' of geophysical data that can be digitally processed in order to improve the information extraction (Gibson and Lyle 1993).

Gravity and aeromagnetic data for the $60 \mathrm{~km}$ $\times 60 \mathrm{~km}$ box shown in Fig. 2 were provided by the Geological Survey of Northern Ireland and the British Geological Survey. The 2377 gravity points (ranging from $-9 \mathrm{mGal}$ to $+26 \mathrm{mGal}$ ) for this area were converted into a grid using an inverse distance algorithm within ERDAS image processing software and then displayed such that the darker areas represent lower gravity readings (Fig. 3a). The Tow Valley Fault Zone is easily recognised as the NE-SW trend across which there is a pronounced decrease in gravity (darker signature) to the north-west due to the presence of thick low-density sediments beneath the basalt. The Tow Valley Fault Zone does not appear to be a single feature but is formed of at least two main segments (Fig. 4a). The 'flexure' between the segments is associated with higher gravity values (A, Fig. 4a). North of the Tow Valley Fault Zone, the higher gravity readings over a low-frequency feature (B, Fig. 4a) correlate with the feature referred to as the Ardmore Anticline and its ENE extension. This

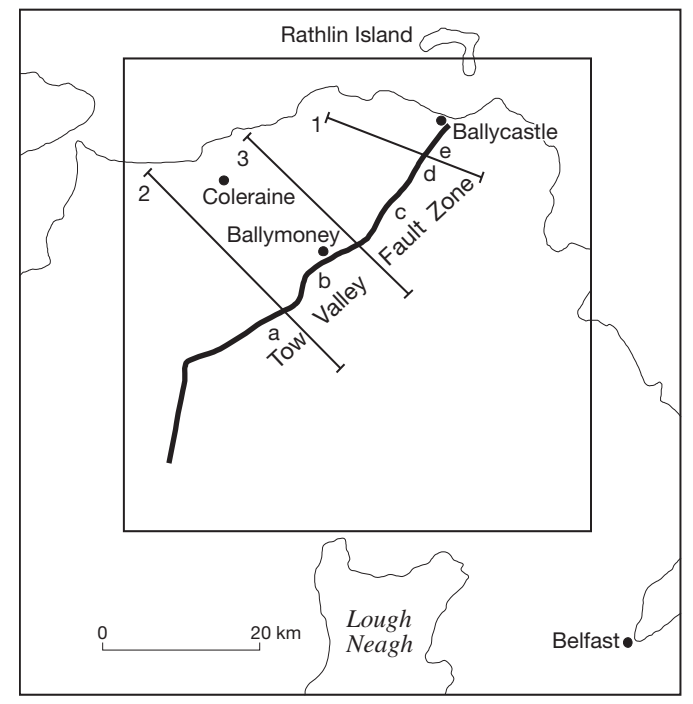

Fig. 2-Locations where data were collected. Numbered lines show gravity profiles (Fig. 5); letters show where ground magnetic data were obtained (Fig. 6) and box is the area portrayed as gravity (Fig. 3a) or aeromagnetic images (Fig. 3b).

dies out towards the north-east resulting in a widening of the North Antrim Basin. The Lough Foyle Fault (LFF, Fig. 4a), where localised deposition has occurred, is located north-west of the Ardmore Anticline. Two areas of low gravity readings south of the Tow Valley Fault Zone ( $\mathrm{C}$ and D, Figs $3 \mathrm{a}$ and 4a) indicate thick sedimentary deposits. The former (C) is the northern part of the Lough Neagh basin, and the latter (D) is the western edge of the Larne basin. The highest gravity, shown by bright tones, is located to the east of centre of the image and covers an area of approximately $200 \mathrm{~km}^{2}$. Apart from the Tow Valley Fault zone, no other major gravity lineaments can be detected, although there are some subtle trends. For example three narrow, N-S-striking zones with low gravity readings terminate at the Tow Valley Fault zone (E, F, G, Fig. 4a).

The 4101 aeromagnetic readings (ranging from $-730 \mathrm{nT}$ to $+762 \mathrm{nT}$ ) for the area shown in Fig. 2 were converted into an image that was digitally pseudo-illuminated from the north-west in order to highlight the fault zone and other structures with a similar trend. The offset seen on the gravity image can be clearly seen on the aeromagnetic image; this offset is not unique but is only the most prominent one (Fig. 3b). The 

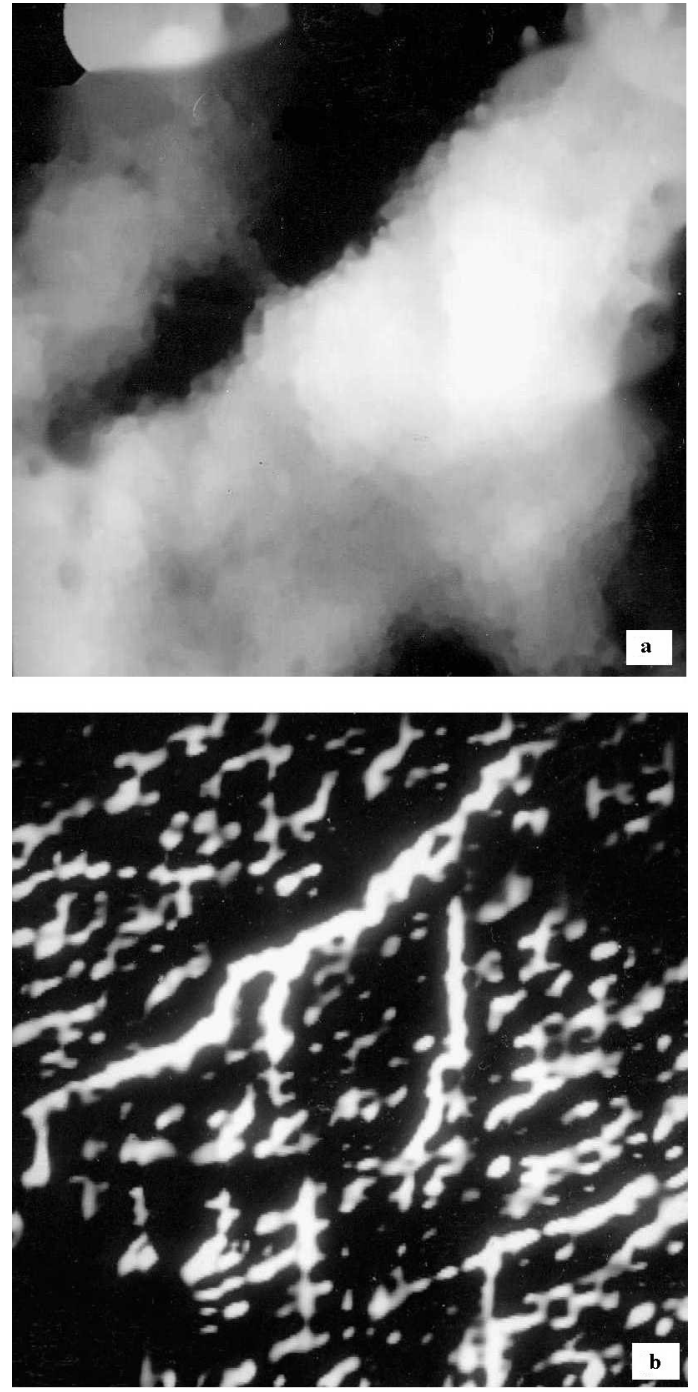

Fig 3-Geophysical images of Tow Valley fault. (a) Gravity image in which the darker areas represent lower gravity readings. (b) Directionally filtered aeromagnetic image.

Tow Valley Fault Zone onshore is formed of five ENE-WSW segments connected by shorter N-S trending ones (Fig. $3 \mathrm{~b}$ and $4 \mathrm{~b}$ ). Two major lineament trends dominate the scene south of the Tow Valley Fault Zone, N-S and ENE-WSW, whereas such trends north of the fault do not appear significant.

\section{Gravity modelling}

Analysis of the geophysical imagery allows a spatial qualitative comparison to be made, thus the gravity image shows that low density sediments are located to the north-west of the Tow Valley Fault Zone. However, it is necessary to model the gravity data to produce quantitative results, i.e. sediment thickness, basin morphology and fault plane orientation. Three profiles were analysed using the British Geological Survey GRAVMAG program (see Fig. 2 for location of profiles). For this study, the original gravity values with their geographical locations and elevations were used. Any single linear traverse across the Tow Valley Fault Zone would intercept a limited number of gravity stations, therefore a specific corridor width was input into the program to extract the relevant data. The corridor width for the profiles averaged $7 \mathrm{~km}$, and a tessellation process sampled the traverse at $0.5 \mathrm{~km}$ intervals. A regional field of $21 \mathrm{mGal}$ was used in the modelling (Carruthers et al. 1987).

The variation of assigned lithological densities from the background density is the important factor in the computation of gravity profiles rather than their absolute values. A background density of $2.74 \mathrm{Mg} \mathrm{m}^{-3}$ was adopted for this study, similar to that adopted by other workers in northern Ireland (Carruthers et al. 1987). The Lough Neagh Group in north-east Ireland is composed mainly of clay, lignite and unconsolidated glacial sands and has a measured density of $2.1 \mathrm{Mg} \mathrm{m}^{-3}$. The Tertiary lavas and Chalk in the Port More borehole have densities of $2.65 \mathrm{Mg} \mathrm{m}^{-3}$ and $2.59 \mathrm{Mg} \mathrm{m}^{-3}$ respectively, and these values were used in the modelling. The Carboniferous and Permo-Triassic sediments were modelled with a single value of $2.49 \mathrm{Mg} \mathrm{m}^{-3}$, similar to that used by Carruthers et al. (1987) for sediments adjacent to the Tow Valley Fault Zone. Dalradian metasediments range in density from $2.74 \mathrm{Mg} \mathrm{m}^{-3}$ to $2.79 \mathrm{Mg}$ $\mathrm{m}^{-3}$. Jurassic (Lias) sediments form about $15 \%$ of the sedimentary sequences in the Port More borehole. However, sediments from the Jurassic period are sparse in north-east Ireland. Consequently modelling was performed assuming that the gravity anomaly was caused only by Permo-Triassic and Carboniferous sediments. A density value of $2.4 \mathrm{Mg} \mathrm{m}^{-3}$ has been given for the Lias (Wilson and Manning 1978), lower than that used for the PermoTriassic and Carboniferous sediments here. Thus 

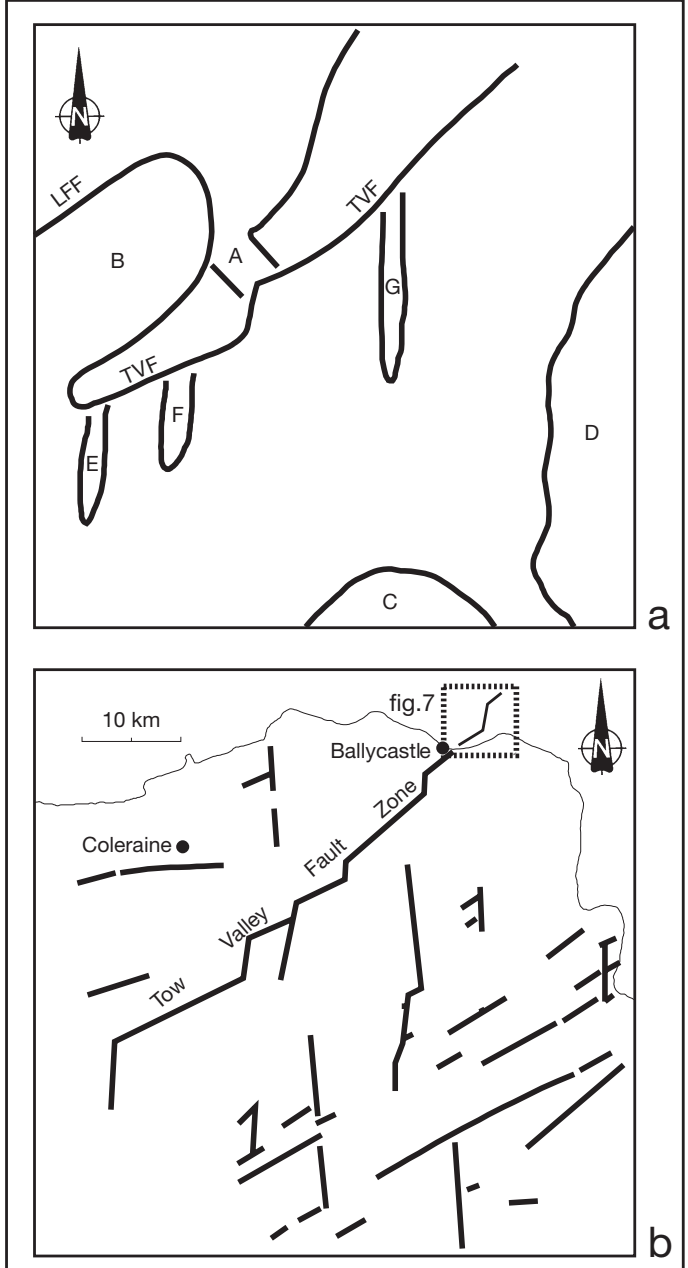

Fig. 4-(a) Interpretation of gravity image. (b) Interpretation of aeromagnetic image. The box shows the location of Fig. 7.

if the Lias forms a substantial part of the sedimentary sequences, then the depths of the north Antrim basin calculated here are a slight overestimate.

Profile 1 was taken close to the Port More borehole, which allowed some control of the thickness of different lithologies. Murlough Bay schists crop out south-east of the Tow Valley Fault Zone, whereas Tertiary basalts underlain by Chalk and thick Permo-Triassic sediments occur to the north-west. The Bouguer gravity variation is that of a gentle south-eastwards reduction from $4 \mathrm{mGal}$ to $-3 \mathrm{mGal}$ adjacent to the Tow Valley Fault Zone followed by a marked increase of $24 \mathrm{mGal}$ at the fault (Fig. 5a). Gravity readings over the Dalradian of the Highland
Border Ridge south of Ballycastle are reasonably constant at $21 \mathrm{mGal}$.

Modelling and altering the subsurface geometry produced the calculated anomaly shown in Fig. 5a. Using only the background density of $2.74 \mathrm{Mg} \mathrm{m}^{-3}$, the calculated anomaly over the Dalradian was too low: rocks of a higher density must be present at depth. This has been modelled as a $800 \mathrm{~m}$ thick higher density prism $\left(2.79 \mathrm{Mg} \mathrm{m}^{-3}\right)$, which is within the range of densities expected for the Dalradian. Sediment thicknesses increase towards the Tow Valley Fault Zone from $1.5 \mathrm{~km}$ to $3 \mathrm{~km}$ close to the fault, which dips to the north-west at about $25^{\circ}$.

The gravity variation along Profile 2 (Fig. 5b) shows a gentle rise from $9 \mathrm{mGal}$ to $13 \mathrm{mGal}$ at $8 \mathrm{~km}$ followed by a drop to a minimum of $4 \mathrm{mGal}$ at $19 \mathrm{~km}$. South-eastwards, the gravity readings increase to a maximum of $18 \mathrm{mGal}$ at $24 \mathrm{~km}$ and then decrease to $13 \mathrm{mGal}$ at $36 \mathrm{~km}$. Modelling produces results similar to Profile 1, though the thickness of sediments adjacent to the Tow Valley Fault Zone are less $(2.1 \mathrm{~km})$ and the dip to the north-west is $20^{\circ}$ (Fig. 5b). The structure referred to as the Ardmore Anticline is very prominent on this traverse (A, Fig. 5b), and it is bounded to the north-west by the Lough Foyle fault. A sedimentary wedge thickens to $1 \mathrm{~km}$ south of the Tow Valley Fault Zone.

Gravity readings decrease from $9 \mathrm{mGal}$ to $-1 \mathrm{mGal}$ at $17 \mathrm{~km}$ on profile 3 , and to the south of the fault a constant value of $23 \mathrm{mGal}$ is maintained (Fig. 5c). The depth of the sedimentary basin is generally between $1.2 \mathrm{~km}$ and $1.5 \mathrm{~km}$, though localised downwarping adjacent to the Tow Valley Fault Zone increases the thickness to $2.4 \mathrm{~km}$. The fault plane again dips to the north-west, albeit at $56^{\circ}$, which is considerably steeper than the $20^{\circ}$ and $25^{\circ}$ dip modelled for the profile to the north-east (profile 1) or south-west (profile 2).

\section{Ground-based magnetic signatures for the Tow Valley Fault Zone}

Although the aeromagnetic data examined earlier allow the gross magnetic signature for the Tow Valley Fault to be evaluated, the data are collected along flight-lines that are on average $2 \mathrm{~km}$ apart, thus fine detail is not detected. Five 


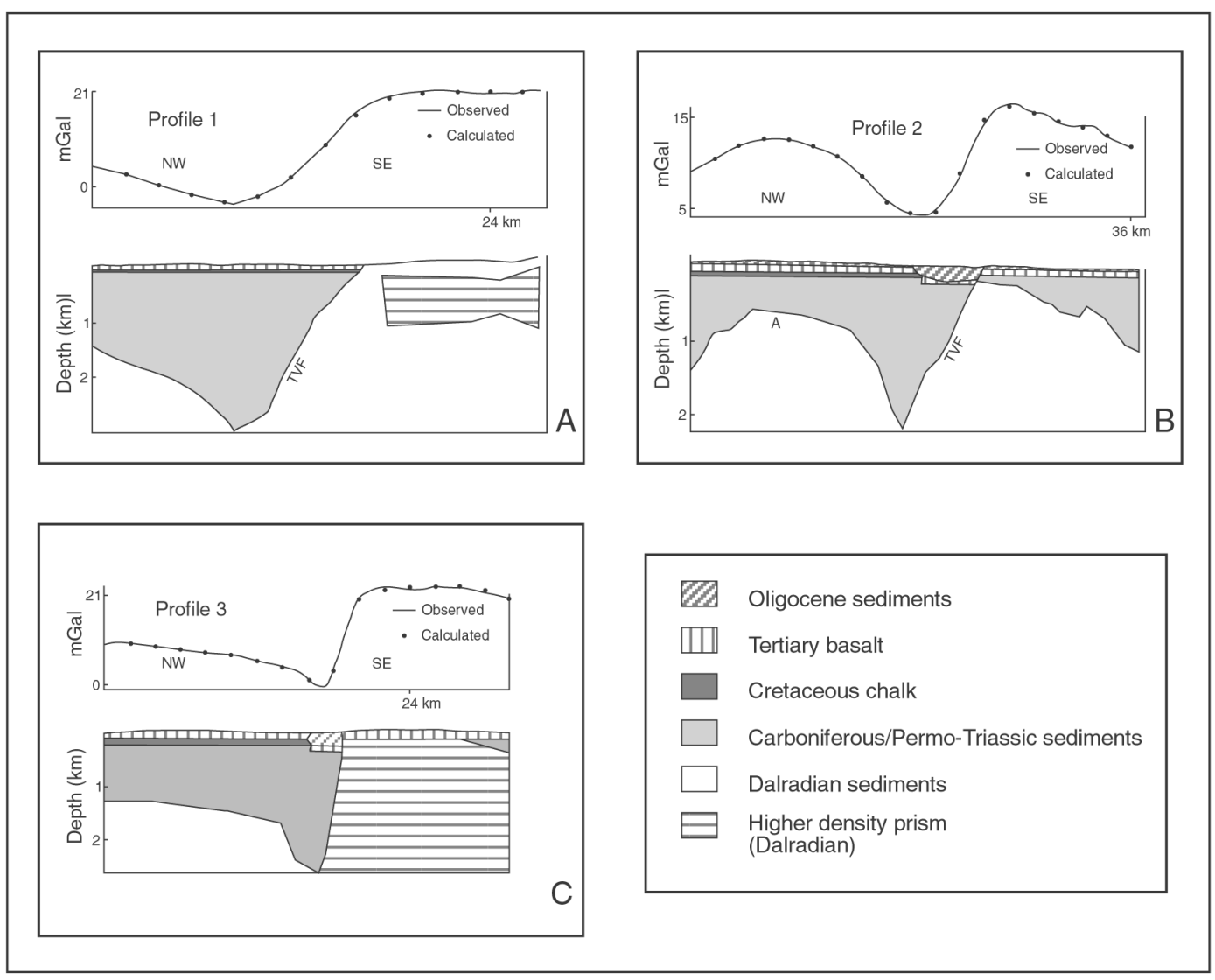

Fig 5-Interpretation of gravity profiles across the Tow Valley Fault. Note that the vertical and horizontal scales are different

magnetic traverses were obtained at the locations shown in Fig. 2.

Magnetic traverse A was taken from the Tertiary basalts (south-east of the fault) into the Tertiary Agivey basin (north-west of the fault). The Tow Valley Fault is characterised by a $1.2 \mathrm{~km}$-wide fault zone bounded by two faults (1 and 2, Fig. 6a) with prominent magnetic signatures. Fault 1 (2000nT anomaly) separates the Agivey sedimentary basin (A, Fig. 6a) from the basalts (B, Fig. 6a). Fault 2 is within the basalts $(1800 \mathrm{nT})$. The fault zone is characterised by high-frequency, large-amplitude magnetic anomalies much greater than the background variance of 200-400nT for the basalts. A prominent peak and trough within the fault zone has a greater amplitude than either Fault 1 or 2 . Amplitudes decrease away from this peak and trough, suggesting that it is the zone of most intense fracturing. Magnetic Traverse B was taken across the Tow Valley Fault Zone near
Ballymoney and the signature for the fault is unlike Traverse 1. A fault is sharply defined by a very prominent 1600 nT anomaly separating the sedimentary basin ( $S$, Fig. 6b) from the basalts (B). The contact is much narrower than for Traverse 1 with no evidence for intense fracturing. Magnetic Traverse C was obtained near Armoy where basalts occur either side of the fault (Fig. 6c). The fault is shown by a $800 \mathrm{~m}-$ wide zone of large variance, high-frequency signatures because the basalt is highly fractured (1600-2400m on Fig. 6c). It is difficult to estimate 'background' magnetic values for this area, but it is approximately 48,900nT to the north-west and 49,300nT to the south-east, probably indicating some relative vertical movement that has juxtaposed lavas with different magnetic characteristics. The highest magnetic value recorded anywhere along the Tow Valley Fault $(>52,000 n T)$ was found on this traverse. 
Traverse D, 3km north-west of Armoy, shows a very sharply defined anomaly of $5000 \mathrm{nT}$ separating basalts with a variable signature averaging 48,500nT (B, Fig. 6d) from an area where there is little magnetic variation. In the far south-east, Dalradian rocks are exposed (D, Fig. 6d), but the 5000nT anomaly is apparently not caused by the Tow Valley Fault. The anomaly located on this traverse is discussed in detail later. Magnetic traverse E revealed two magnetic anomalies, one of $4700 \mathrm{nT}$ (1, Fig. 6e) and one of 3500nT (2, Fig. $6 e)$. The former anomaly is within the basalts (B), whereas the latter is where Dalradian rocks (D) are faulted against basalt.

\section{Offshore continuation of the Tow Valley Fault Zone}

The offshore geology of north-east Ireland is essentially a continuation of onshore lithologies though precise contacts are more difficult to detect. Dalradian metasediments of the Highland Border ridge extend northwards from Ballycastle and are associated with faultbounded inliers of Carboniferous, Mesozoic and Tertiary rocks. The Rathlin Trough continues offshore with a south to south-east younging direction for the Triassic marls and sandstones, whereas the Tertiary basalts on the mainland and on Rathlin Island do not extend far offshore (Dobson and Evans 1974; Evans et al. 1979).

Onshore the Tow Valley Fault Zone is characterised by steep magnetic gradients, though a reduced magnetic gradient is continued offshore from Ballycastle for $6 \mathrm{~km}$ with a slight change in trend. The contours are deflected northwards (sub-parallel to the eastern edge of Rathlin Island) and a possible north-easterly extension is indicated by a steep magnetic gradient 8km north-east of Rathlin.

Some of the lowest gravity readings in northern Ireland are found offshore close to Rathlin Island ( $-5 \mathrm{mGal}$ to $-9 \mathrm{mGal})$. A change in strike to a N-S trend for the gravity contours near Rathlin, similar to that shown by the magnetic contours, is recorded by Evans et al. (1979) and Carruthers et al. (1987).

A number of reflection seismic lines were shot across the Rathlin Trough for Energy
Resources Limited in the 1980s: some of these were in areas through which any offshore continuation of the Tow Valley Fault Zone would be likely to pass (Fig. 7). Interpretations of some of these seismic profiles are given in Fig. 8. The Tow Valley Fault Zone is clearly shown on Line 1 by the abrupt termination of reflectors, thus the fault extends to $55^{\circ} 19^{\prime} \mathrm{N}$, $6^{\circ} 7^{\prime} \mathrm{W}\left(4.5 \mathrm{~km} \mathrm{~N} 65^{\circ} \mathrm{E}\right.$ of Rathlin Island). No reflectors can be detected in the Dalradian sequences to the east of the fault, whereas to the west, dipping reflectors in the Permo-Triassic strata are very evident (Fig. 8a.). Upturning of the sedimentary sequences occurs about $2.5 \mathrm{~km}$ from the fault due to fault drag and is consistent with normal faulting with a north-west downthrow similar to that onshore. Interpretation of Line 2 is similar to Line 1, though the presence of reflectors in the Dalradian may be due to faulted sedimentary inliers (Evans et al. 1979). Strata are again upturned up to $3 \mathrm{~km}$ from the fault (Fig. 8b). Line 3 farther to the south confirms the more northerly profiles and locates the fault at Grid ref. D184510 (Fig. 8c).

Line 4 is parallel to the eastern edge of Rathlin Island but also indicates the contact between the seismically featureless Dalradian and the reflectors in the Palaeozoic and Mesozoic sediments, which again show upturned reflectors within $2 \mathrm{~km}$ of the Tow Valley Fault Zone (Fig. 8d). Nearer to the north Antrim coast some upturned reflectors are evident in the seismic data at the eastern edge of Line 5 (see Fig. 7), which suggests that the Tow Valley Fault Zone occurs immediately to the east of this seismic line and its inferred position is approximately $500 \mathrm{~m}$ to the east (Gibson 1991). This change in strike from that onshore mirrors the displacement of the magnetic gradient, thus locally the Tow Valley Fault Zone is sub-parallel to the coast. The location of Fig. 7 in relation to the onshore section of the Tow Valley Fault Zone as mapped from directionally filtered aeromagnetic data is shown in Fig. 4b. There is an obvious continuity of structural style offshore with the fault onshore, with it continuing to be formed of ENE-WSW trending segments connected by $\mathrm{N}-\mathrm{S}$-trending ones. 


\section{Discussion}

An examination of Fig. 6d shows that magnetic readings obtained over Dalradian rocks that are very weakly magnetic are higher than over the basalts which are highly magnetic. This is because the Tertiary volcanic rocks in north-east Ireland are reversely magnetised with a mean inclination of $-54^{\circ}$ and a declination of $185^{\circ}$ (Wilson 1970), thus the total field as measured by a proton magnetometer would be expected to be lower over the basalts. However, in the Ballymoney area, magnetic readings south-east of the Tow Valley Fault Zone, where basalt is near the surface, are higher than over the sedimentary basin, where the basalt is located much deeper (Fig. 6b). For reversely magnetised basalts, readings should be lower where the basalt is closer to the surface. Similarly, in Fig. 6a, in the same area, readings over the basalt south-east of the fault are greater $(>50,300 \mathrm{nT})$ than over the sedimetary basin
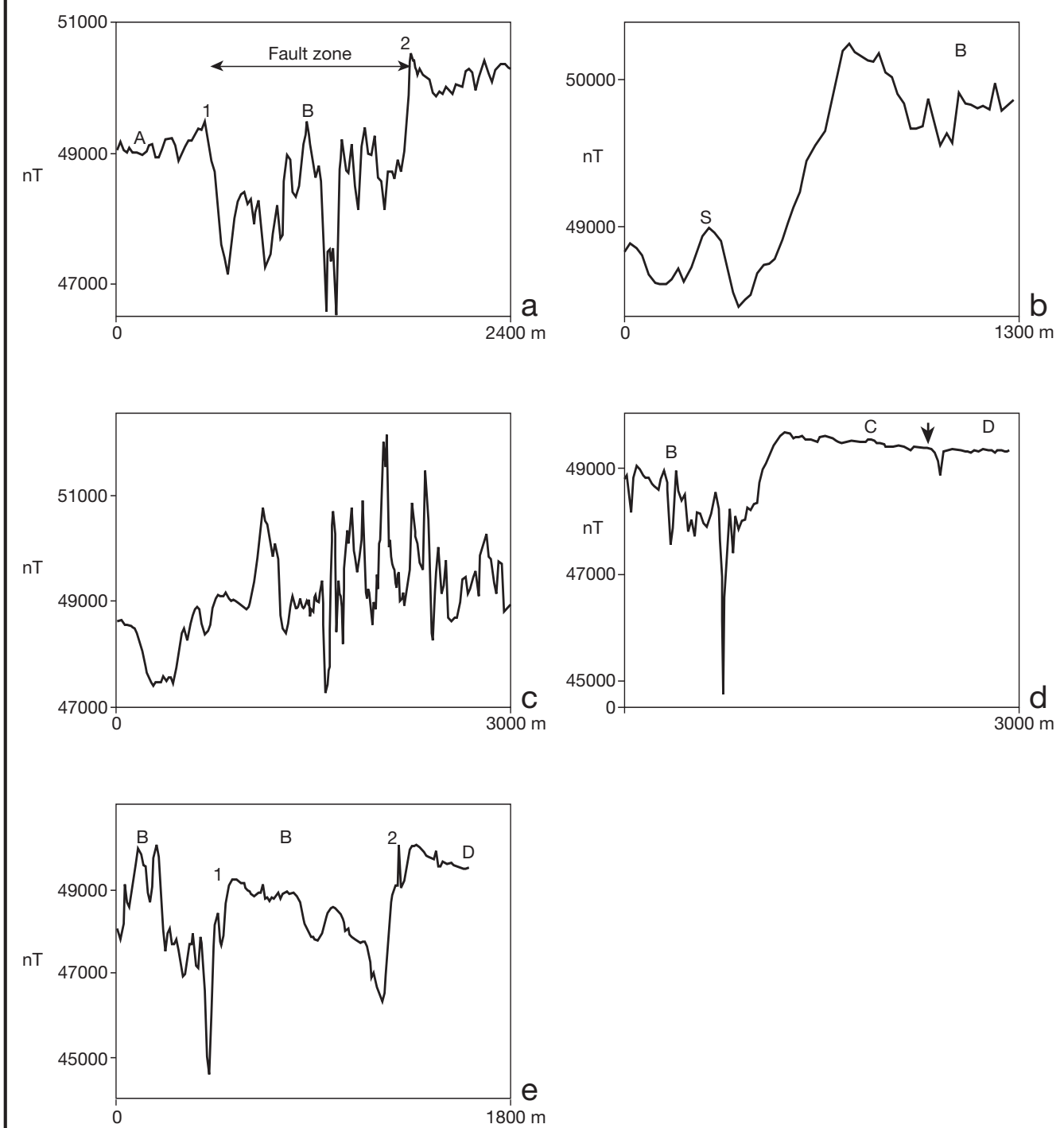

Fig 6-Ground-based magnetometer profiles across the Tow Valley Fault. Letters on Fig. 2 show the locations. Arrow on Fig. $6 \mathrm{~d}$ shows probable location of Tow Valley Fault. 
(49,200nT). These anomalies can be best reproduced by assuming the presence of a highly magnetic body south-east of and adjacent to the Tow Valley Fault. The body is possibly serpentinite, which occurs along the
Fair Head - Clew Bay Lineament in the Clew Bay region. The Clew Bay serpentinites are highly magnetic and have been associated with positive anomalies of 3000-8000nT (Gibson et al. 1996).

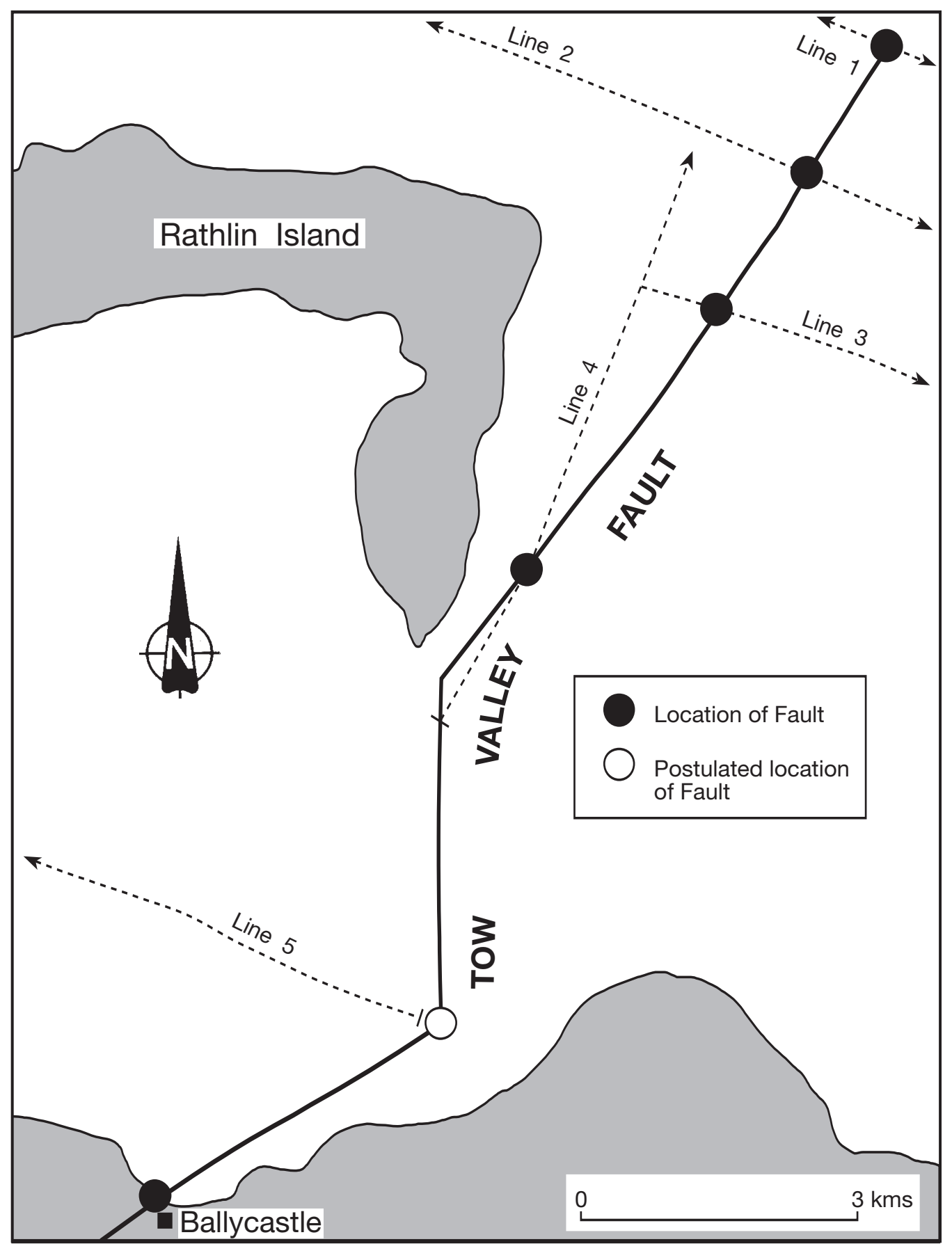

Fig. 7-Location of offshore seismic lines and position of Tow Valley Fault. 
If the large magnetic anomaly shown in Fig. $6 \mathrm{~d}$ is modelled, the best fit is obtained for a high angle reverse fault (Gibson 1991). The Tow Valley Fault is a normal fault downthrowing to the north-west and this orientation cannot reproduce the observed
5000nT magnetic anomaly. Kerr (1987), who modelled a similar magnetic traverse obtained in the same area, also concluded that a reverse fault was present. There are no exposures on this traverse between Dalradian outcrops in the south-east (2000m on Fig. 6d) and basalts in
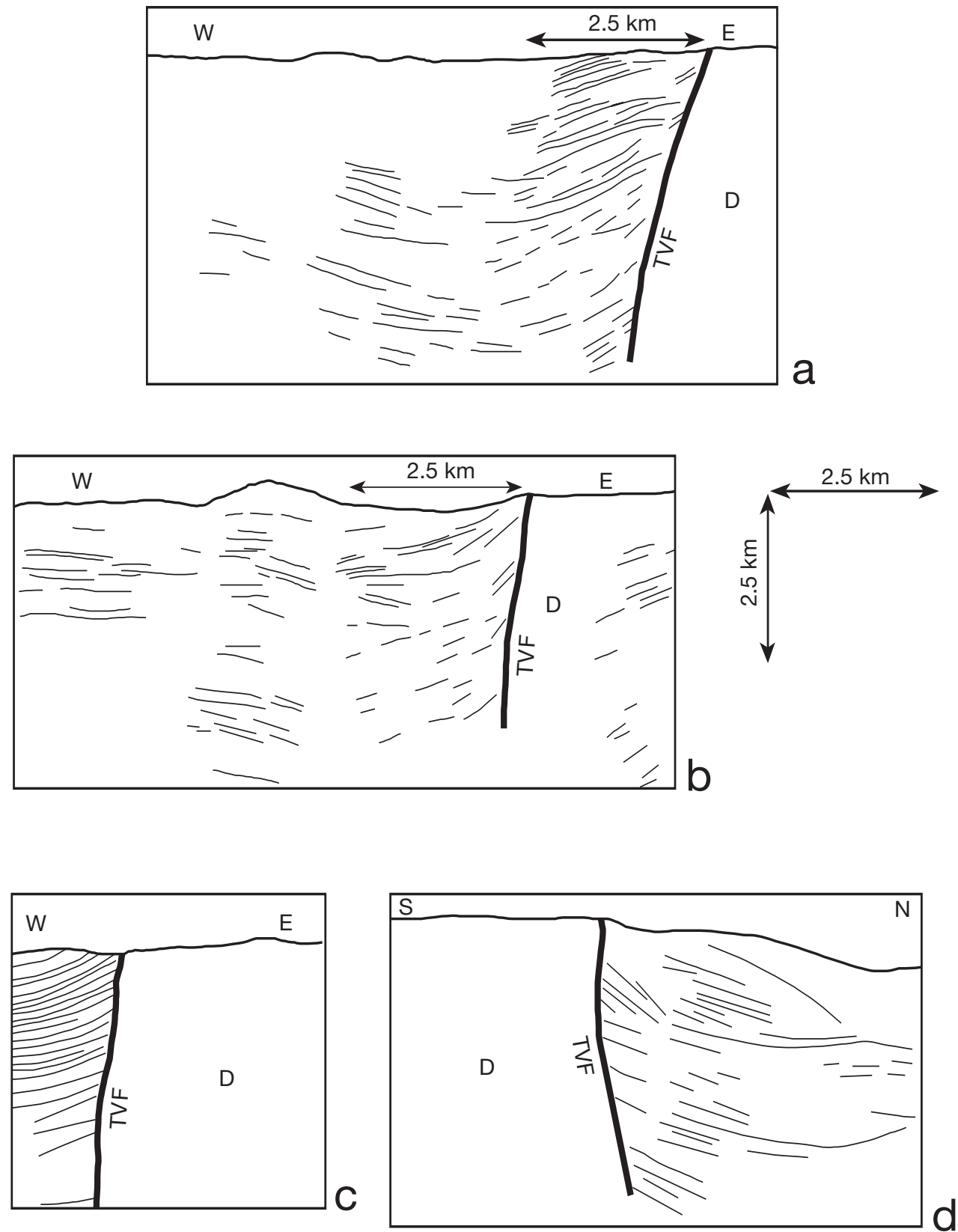

Fig 8-Interpretation of offshore seismic lines. Fig. 8a: line 1; Fig. 8b: line 2; Fig. 8c: line 3; Fig. 8d: line 4. 


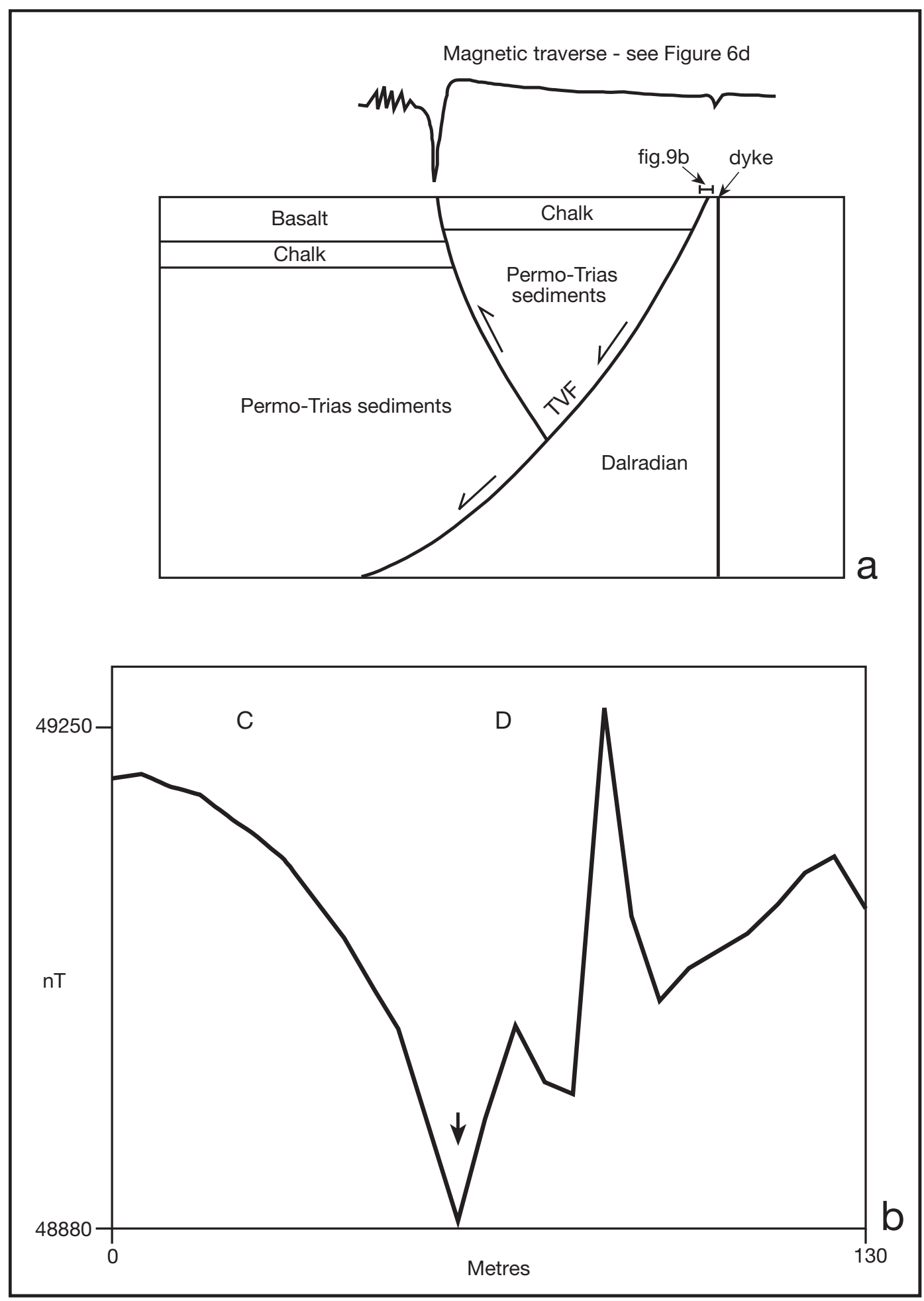

Fig. 9-(a) Explanation of magnetic traverse shown in Fig. 6d and (b) magnetic traverse across the Tow Valley Fault at this locality. Arrow shows probable location of Tow Valley Fault (see also Fig. 6d). 
the north-west, though Cretaceous Chalk is located nearby. A geological model to explain this magnetic traverse is shown in Fig. 9a. In this location, the Tow Valley Fault is represented by the normal faulting of chalk and Dalradian lithologies and the reverse fault is an accommodation structure. A small negative anomaly located at $2020 \mathrm{~m}$ on Fig. $6 \mathrm{~d}$ is associated with a Tertiary dyke. A pronounced break in slope on this traverse probably represents the location of the Tow Valley Fault (Dalradian faulted against chalk) and is associated with a magnetic anomaly (Fig. 9b).

A comparison of the aeromagnetic gradient and the ground-based magnetic traverses show discrepancies at some locations. Between Garvagh and Ballymoney, the aeromagnetic gradient and the location of the Tow Valley Fault as determined from ground magnetic surveys coincide for example on Fig. 6a and 6b. In the Armoy-Ballycastle region, the main aeromagnetic gradient is approximately $1 \mathrm{~km}$ north-west of the position of the fault as determined from ground magnetic surveys. The main aeromagnetic gradient corresponds with the localised magnetic trough at 50m on Fig. 6c, the 5000nT anomaly on Fig. 6d (which is not caused by the Tow Valley Fault, see Fig. 9) and Fault 1 on Fig. 6e (which is within the basalts). The more accurate ground-based magnetic surveys located the Tow Valley Fault to the SE of these positions.

\section{Conclusions}

The Tow Valley Fault Zone is characterised by large gravity and magnetic anomalies and is one of the most important geological structures in north-east Ireland. Vertical movement began in the early Devonian. It is a normal fault with an estimated maximum north-west downthrow of $2.4 \mathrm{~km}$ with most deposition occurring during the Permo-Triassic. Seismic data show that the fault continues offshore. The Tow Valley Fault should more properly be referred to as the Tow Valley Fault Zone because it is seen to consist of a number of main ENE-WSW trending fault segments and shorter N-S ones with different dips, downthrows and geophysical characteristics.

\section{Acknowledgements}

The author would like to thank the Geological Survey of Northern Ireland and the British Geological Survey (BGS) for access to the geophysical data and for the use of a magnetometer.

\section{References}

British Geological Survey 1997 Colour shaded relief gravity anomaly map of Britain, Ireland and adjacent areas. Scale 1:1,500,000. Nottingham. British Geological Survey.

British Geological Survey 1998 Colour shaded relief magnetic anomaly map of Britain, Ireland and adjacent areas. Scale 1:1,500,000. Nottingham. British Geological Survey.

Carruthers, R.M., Cornwell, J.D., Turnbull, G., Walker, A.S.D. and Bennett, J.R.P. 1987 Interpretation of the Bouguer gravity anomaly data for Northern Ireland. Report of the British Geological Survey Vol. 5, No.?. London..

Dewey, J.F. and Shackleton, R.M. 1984 A model for the evolution of the Grampian tract in the early Caledonides and Appalachians. Nature 312, 115-20.

Dobson, M.R. and Evans, D. 1974 Geological structures of the Malin Sea. Journal of the Geological Society, London 130, 475-8.

Evans, D., Kenolty, N., Dobson, M.R. and Whittington, R.J. 1979 The geology of the Malin Sea. Institute of Geological Sciences Report 79/15.

Geological Survey of Northern Ireland 1997 Northern Ireland. Solid Geology (2nd edn), 1:250,000. Nottingham. British Geological Survey.

Geological Survey of Northern Ireland 1999 Northern Ireland Sheet 13, Coleraine: Solid and Drift Geology, 1:50,000. Nottingham. British Geological Survey.

Gibson, P.J. 1991 An integrated investigation of the Tow Valley Fault system, Ireland, with particular reference to remote sensing techniques. Unpublished $\mathrm{PhD}$ thesis, University of Ulster, Coleraine.

Gibson, P.J. and Lyle, P. 1992 The interpretation of a major non-Caledonian structural lineament in north-east Ireland. Irish Journal of Earth Sciences 11, 181-5.

Gibson, P.J., Lyle, P., and George, D.M. 1996 Ground-based magnetic patterns across selected Irish rocks and structures. Irish Journal of Earth Sciences 15, 129-43.

Hutton, D.H.W. 1987 Strike-slip terranes and a model for the evolution of the British and Irish Caledonides. Geological Magazine 124, 405-35.

Kerr, I.D.V. 1987 Basement/cover structural relationships in the north Antrim area, Ireland. Unpublished $\mathrm{PhD}$ thesis, Queen's University Belfast.

Murphy, F.C., Anderson, T.B., Daly, J.S., Gallagher, V., Graham, J.R., Harper, D.A.T., Johnston, J.D., Kennan, P.S., Kennedy, M.J., Long, C.B., Morris, J.H., O'Keeffe, W.G., Parkes, M., Ryan, P.D., Sloan, R.J., Stillman, C.J., Tietzsch-Tyler, D., Todd, S.P. and Wrafter, J.P. 1991 An appraisal of Caledonian suspect terranes in Ireland. Irish Journal of Earth Sciences 11, 11-41. 
Parnell, J., Shukla, B. and Meighan, I.G. 1989 The lignite and associated sediments of the Tertiary Lough Neagh Basin. Irish Journal of Earth Sciences 10, 67-88.

Ryan, P.D., Sawal, V.K. and Rowlands, A.S. 1983 Ophiolitic melange separates ortho- and paratectonic Caledonides in western Ireland. Nature 302, 50-2.

Sanderson, D.J. 1970 The Highland Border Ridge of northeast Ireland. Geological Magazine 107, 531-8.

Simon, J.B. 1984 Provenance and depositional history of the lower Old Red Sandstone of north-east Antrim. Irish Journal of Earth Sciences 6, 1-13.

PAUL J. GIBSON

Department of Geography,

National University of Ireland, Maynooth,

Maynooth,

Co. Kildare,

Republic of Ireland.

E-mail: paul.gibson@may.ie
Wilson, H.E. and Manning, I. 1978 Geology of the Causeway Coast. Vol. 2. Belfast. Her Majesty's Stationery Office.

Wilson, R.L. 1970 Palaeomagnetic stratigraphy of Tertiary lavas from Northern Ireland. Geophysical Journal of the Royal Astronomical Society 20, 1-9. 


\title{
COPYRIGHT INFORMATION
}

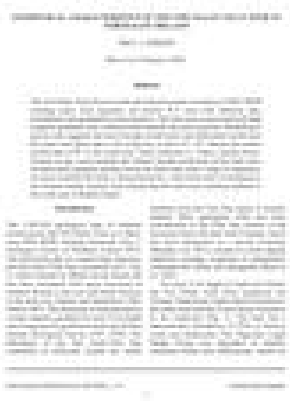

\author{
Author: Gibson, Paul J.
}

Title: Geophysical characteristics of the Tow Valley Fault Zone in north-east Ireland

Source: Ir J Earth Sci 222004 p. 1-13

ISSN: 0790-1763

Publisher: Roayl Irish Academy

19 Dawson Street, Dublin 2, Ireland

The magazine publisher is the copyright holder of this article and it is reproduced with permission. Further reproduction of this article in violation of the copyright is prohibited. To contact the publisher: http://www.ria.ie

\footnotetext{
This article may be used for research, teaching and private study purposes. Any substantial or systematic reproduction, re-distribution, re-selling, loan or sublicensing, systematic supply or distribution in any form to anyone is expressly forbidden. The publisher does not give any warranty express or implied or make any representation that the contents will be complete or accurate or up to date. The accuracy of any instructions, formulae and drug doses should be independently verified with primary sources. The publisher shall not be liable for any loss, actions, claims, proceedings, demand or costs or damages whatsoever or howsoever caused arising directly or indirectly in connection with or arising out of the use of this material.
} 